Article

\title{
A Techno-Economic Analysis of Off-Grid Solar PV System: A Case Study for Punjab Province in Pakistan
}

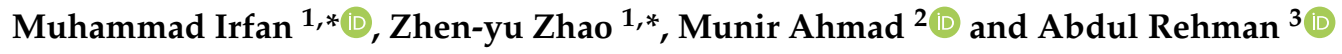 \\ 1 Beijing Key Laboratory of New Energy and Low Carbon Development, School of Economics and \\ Management, North China Electric Power University, Beijing 102206, China \\ 2 School of Economics, Zhejiang University, Hangzhou 310027, China; munirahmad@ncepu.edu.cn \\ 3 Research Center of Agricultural-Rural-Peasants, Anhui University, Hefei 230039, China; \\ abdlrehman@ahu.edu.cn \\ * Correspondence: irfan@ncepu.edu.cn (M.I.); zhaozhenyuxm@263.net (Z.-y.Z.); Tel.: +86-156-1189-7375 (M.I.); \\ $+86-10-6177-3150$ (Z.-y.Z.)
}

Received: 21 July 2019; Accepted: 17 September 2019; Published: 7 October 2019

check for updates

\begin{abstract}
Fossil fuels are the primary sources of electricity generation in Pakistan. The energy demand and supply gap have intensified recently due to the massive population and fossil fuels are unable to meet the gigantic energy requirement of the country. Meanwhile, they also have adverse environmental impacts. Remote rural regions that are far away from the national grid do not have any means to fulfill their energy needs. The off-grid solar photovoltaic (PV) system has emerged to be the best energy option to electrify these remote regions. However, the strategic problem pertaining to local electricity generation is the absence of the area-specific generation capacity and economic feasibility data for solar energy. To address this problem, this study aims to assess the potential and economic viability of utilizing an off-grid solar PV system for rural electrification in the Punjab province of Pakistan. The research results reveal that there is an excellent solar irradiance in the rural areas of Punjab for electricity generation. In addition, suitable tilt angles have been calculated to increase the energy output of solar PV in the respective regions. Furthermore, this study has undertaken the economic viability for solar PV systems, and it was found that electricity generation from the solar PV costs Pakistani rupees (PKR) 7.15 per kWh and is much cheaper than conventional electricity, which costs PKR 20.7 per kWh. Besides, the system can reduce carbon emissions considerably. If $100 \%$ of the unelectrified households adopt solar PV system, then 617,020 metric tons of $\mathrm{CO}_{2}$ could be mitigated annually. Based on research findings, this study has suggested essential policy recommendations that would serve as a guideline for the government and stakeholders to maximum deploy the off-grid solar PV rural electrification programs in Punjab as well as on a national scale.
\end{abstract}

Keywords: off-grid solar PV system; remote regions; rural electrification; economic feasibility; $\mathrm{CO}_{2}$ mitigation

\section{Introduction}

Electricity is the backbone for the economic and social development of a country. However, 1.1 billion people are living without electricity in the world [1]. Most of the population experiencing this situation belongs to the rural areas of Sub-Saharan Africa and South Asia [2,3]. A large population of Pakistan is living in rural areas, and most of them do not have electricity access. Being a developing country, Pakistan is facing social and environmental challenges. Moreover, the ever-increasing population has raised the demand for energy in the country. The current power demand of the country is 25,000 megawatts (MW), whereas the power supply is only $17,000 \mathrm{MW}$, producing a gap of $8000 \mathrm{MW}$ [4]. As a result, the electricity shortfall is $12 \mathrm{~h} /$ day in urban areas and 
$18 \mathrm{~h} /$ day in rural areas [5]. The situation is even worse in the remote rural areas of Punjab, where the shutdown of electricity lasts for many days. It is estimated that Pakistan's power demand can further increase up to 40,000 MW by 2030 [6].

The current energy structure of Pakistan is dependent on fossil fuels. Thermal energy (coal, oil, and gas) fulfills $86.5 \%$ of the country's energy needs [7]. This massive dependence on fossil fuels has led to severe environmental problems, including an increase in carbon emissions, erratic weather patterns, oil uncertainty and global warming [8]. Therefore, the government is looking for alternative and clean energy sources to mitigate these environmental problems. Pakistan has vast renewable energy potential for electricity generation. Wind sources have the potential of 346 gigawatts (GW), whereas, solar energy (2900 GW), hydropower (6 GW), and biomass (5 GW), respectively [9].

The provincial government of Punjab is effectively tapping renewable energy (RE) to generate electricity. Despite sincere government's efforts, the rural areas of the province have low electrification due to four major reasons. First, $37 \%$ of Punjab's population is living in rural areas and approximately 7432 villages are still un-electrified [10]. These areas are scattered far away from the national grid. It is uneconomic and very expensive to connect these areas with the national grid. Second, the power demand in rural areas is only 50 to 100 Watts per household, which is very low as compared to urban areas [11]. Usually, one to two fans and a small number of electric lights are enough, as these houses merely consist of one room. For such a minimum load, it is very expensive to provide on-grid transmission to these villages [12]. Therefore, there is little possibility of grid-connected electricity in the future. Meanwhile, electricity generation from diesel generators is also an uneconomical option, as it is very costly to transport oil to these remote areas. Third, stakeholders are reluctant to invest in RE projects due to the high initial investment, long payback periods, the remoteness of the regions, and the lack of infrastructure [13]. Finally, the economic condition of the country is fragile and cannot support the import of costly fossil fuels especially oil to overcome energy problems. Therefore, the government has decided to close many ongoing RE projects which have negatively affected the deployment of RE technologies. The Punjab province has suffered the most with this government decision, as newly started projects have shut down completely.

The off-grid solar energy is the most viable solution for electricity generation in the remote areas of the province, by keeping in view the factors as mentioned above $[14,15]$. The province has vast solar energy potential, with more than 300 sunny days and $2 \mathrm{MWh} / \mathrm{m}^{2}$ annual solar irradiation [16]. The Asian Development Bank also reported that the off-grid solar photovoltaic (PV) is the best energy choice for rural regions, as it is cost-effective, easy to install and improves the socio-economic condition of these regions [17]. Many researchers have envisioned solar PV-based off-grid electricity in the remote areas $[18,19]$. Sandwell et al. [20] proposed that the off-grid solar PV is the best and sustainable option for rural regions due to the net energy, low life-cycle cost, and environmental benefits. Mishra and Behera [21] identified that the living standard of people has improved with the development of the solar PV system. The solar PV system does not damage human health, mitigate carbon emissions, and is free from noise pollution [22]. Besides, numerous other studies have shown that the off-grid solar PV system is favorable for the environment and economically the best energy choice for rural electrification [23-25].

Therefore, there should be strong supporting policies to achieve the ambitious goal of rural electrification. In addition, comprehensive research is required to identify the specific regions, assess solar energy potential and analyze the economic viability of utilizing solar PV in these regions. For Punjab province, no such research has been conducted before. Therefore, this study aims to bridge this research gap. Five rural regions of Punjab were selected, namely Bhakkar, Khanewal, Multan, Bahawalnagar and Rajanpur for this purpose. The study has the following main objectives:

- To analyze the techno-economic viability of solar PV-based off-grid system for the rural regions of Punjab.

- To electrify these regions by offering a solar PV-based off-grid system. 
This research is the first attempt to develop solar PV-based off-grid system for Pakistan's Punjab province. The policymakers can take this study as a guide to establish rural programs of solar PV power generation and make procurement strategies which encourages unwilling stakeholders to invest in solar PV projects.

\section{Solar PV Development and Issues in Pakistan}

\subsection{Development of Solar PV in Rural Regions}

Pakistan initiated its first solar PV project in the 1980s. However, due to technical problems, the project failed [26]. Subsequently, the country did not develop any RE-based project until 2005. Later, the government realized to promote the development of RE technologies for electricity generation and established two organizations namely, Pakistan Commission of Renewable Energy Technologies (PCRET) and the Alternative Energy Development Board (AEDB) [27]. Currently, AEDB has planned to set up an off-grid solar PV system in rural regions to electrify 906 houses [28]. The government has clear intentions to enrich the socio-economic development and protect the rural environment by taking the full advantage of solar energy framework.

\subsection{Issues with Solar PV in Rural Regions of Pakistan}

Nonetheless, solar PV is the best option to electrify rural regions, yet its development level is very low in remote areas of Pakistan. The National Electric Power Regulatory Authority (NEPRA) reported that still, 40,000 villages do not have electricity access in the country [29]. The robust coordination is required among organizations for the successful rural electrification programs [30]. Though AEDB and PCRET have been established for the quick deployment of RE technologies in Pakistan, however, both organizations did not achieve the desired results.

Meanwhile, the government has failed in making effective plans and policies to uplift the progress of solar PV system in rural areas [31]. Compared with developed countries, the cost of solar PV is significantly high in Pakistan. The high up-front cost is another major barrier in the progress of solar PV technology [32]. Besides, the government announced a tariff of $32 \%$ on the import of solar PV panels during the finance bill 2014-15, which has resulted in the regress of solar PV. Consequently, the government reversed its decision and reduced tariffs on solar PV panels. Regardless of tariffs on solar PV panels, batteries also have tariffs with approximately $50 \%$. Additionally, householders did not receive any subsidy on the installation of the solar PV system, which indicates the failure of government policies to boost the development of solar energy [33].

\section{Research Methodology}

\subsection{Determining the Solar Energy Potential}

For monitoring the PV system performance, the daily energy output can be computed by using the following equation.

$$
E=A r H
$$

Here, $E$ is the energy output, $A$ is total area of solar panel $\left(\mathrm{m}^{2}\right), r$ is efficiency of solar panel (\%), and $H$ is the daily average solar irradiation in a particular area.

For instance, the average solar irradiation is $5.46 \mathrm{kWh} / \mathrm{m}^{2} /$ day in Bhakkar region and the area of solar panel is $1.2 \mathrm{~m}^{2}$, while solar panel efficiency is $16 \%$, then the daily energy output from solar panels is expected to be $1048 \mathrm{kWh}$.

\subsection{Solar Irradiation and Determining the Optimal Tilt Angle}

The horizontal surface of a particular area is normally used to measure the solar irradiation. A solar panel generates high energy output if it receives direct solar irradiation. Therefore, to increase the efficiency of solar energy output, solar panels are usually angle-tilted [34]. Sometimes, clouds cover 
some part of the sky and this effect is called cloudiness [35]. The PV module does not receive the uniform solar irradiance under this condition which in turn affect its energy yield [36]. Bonkaney et al. [37] studied the effect of cloudiness on the performance of PV module and found out that cloudiness has a great impact on decreasing the daily energy yield of solar PV and this effect is immediate.

However, techniques are available to improve the PV energy yield during cloudy conditions. One such technique is the solar tracking system. A solar tracker is one of the most effective ways to enhance solar energy output. Improving the harvesting of solar energy on cloudy days is important to utilize solar energy to fulfill the daily energy needs of households [38]. Solar trackers change solar PV's angle and, in this way, increase its energy output. However, utilizing solar trackers require huge costs [39]. Thus, these are rarely used in remote rural areas. On the other hand, manually changing the tilt angle of solar panels is more convenient than installing solar trackers [40]. Several techniques have been utilized to calculate the precise title angle of solar panels for exploiting maximum solar irradiance [41-43].

In this paper, a direct beam has been obtained by a tilted horizontal surface, where some irradiations are absorbed, and some diffused, while some show they are off the ground. Thus, on a tilted surface $E \underset{G}{T}$, the global horizontal irradiance is defined as:

$$
E_{G}^{T}=E_{B}^{T}+E \frac{T}{D}+E_{R}^{T}
$$

In this equation, the direct beam is denoted by $E_{B}^{T}$, diffused irradiation by $E_{D}^{T}$, while solar energy's reflected rays on a tilted surface are denoted by $E_{R}^{T}$. Suppose, $H_{B}$ is the ratio for the average daily direct beam on a tilted surface and the average daily direct beam on a horizontal surface, then $E_{B}^{T}$ can be calculated as:

$$
E_{B}^{T}=E_{B} H_{B}
$$

Here $H_{B}$ is a geometric parameter. Therefore, the value depends on horizontal tilt, latitude, declination angle and surface azimuth. To compute $H_{B}$, the Liu and Jordan model [44] has been utilized, as follows.

$$
H_{B}=\frac{\cos (L-T) \cdot \cos G_{s s} \cdot \sin i_{s h}+i_{s h} \cdot \sin (L-T) \cdot \sin G_{s s}}{\cos L \cdot \cos G_{s s} \cdot \sin i_{s h}+i_{s h} \cdot \sin L G_{s s}}
$$

Here, $L$ is the latitude, $T$ is the tilt angle, and $G_{s s}$ and $i_{s h}$ are the declining angles and sunshine hours, respectively. Assume an isotropic distribution of diffused radiation for precision. Thus, the diffused region on the horizontal tilt angle $\lambda$ and horizontal surface are:

$$
E_{D}^{T}=H_{B} \frac{(\cos (\lambda)+1)}{2}
$$

Here, the range of $\omega$ differs from 0.1 to 0.9 [45]. Therefore, the reflected beam can be computed as follows:

$$
E_{R}^{T}=\omega\left(E_{B}+E_{D}\right) \frac{(-\cos (\lambda)+1)}{2}
$$




\subsection{The Economic Viability of Solar PV System}

The following sub-sections assess and analyze the economic viability of solar PV-based off-grid rural power system.

\subsubsection{The Size and Battery Storage of Solar PV System}

The solar PV module, battery storage, DC-AC inverter, and maximum power point tracking (MPPT) system controller are the main parts of a solar PV system. Solar energy received by solar panels is transfer to the system controller. This energy is then converted into DC. In the next step, DC transmits it to the DC-AC inverter. The energy generation capacity of the solar PV system normally depends on the solar irradiation received in a specific area. In addition, other criteria should also be considered, such as the optimal tilt and efficiency of solar panels [46]. It is important to calculate the losses incurred during the DC-AC conversion. There are different models to forecast solar energy output on a tilted solar PV. The potential of electricity generation by solar PV and $I_{p v}(\mathrm{kWh})$ is calculated using the following equation [47].

$$
I_{p v}=A_{p v} \cdot E_{p v} \cdot I_{t} \cdot \mathrm{PR}
$$

In this equation, the panel area is denoted by $A_{p v}$, panel efficiency by $E_{p v}$, annual solar irradiance received on a tilted solar panel by $I_{t}$ and PR is the performance ratio accounting for the losses incurred. Meanwhile, $E_{p v}$ is calculated as [48]:

$$
E_{p v}=E_{r}\left[\lambda_{r}\left\{T_{a}-T_{r}+\left(T_{n}-T_{a . n}\right) \frac{S_{T}}{S_{N}}\right\}\right]
$$

Here, $E_{r}$ is the solar panels' efficiency, $\lambda_{r}$ is the solar panels' temperature, $T_{a}$ is the ambient temperature, $T_{r}$ is the solar panels' referenced temperature, $T_{n}$ and $T_{a . n}$ are the nominal operating temperature and ambient nominal operating temperature of a solar PV cell respectively. Whereas, $S_{T}$ is the solar radiation and $S_{N}$ is the solar radiation for the nominal operating temperature of the solar panel cell test.

The critical task in designing any solar PV system is to estimate the approximate electricity consumption needs of residents. It is necessary to calculate the electricity consumption per household by compiling several appliances, their watt ratings, and then summing up by multiplying the number of hours these appliances have been used with watts rating. The estimated electricity consumption of one household is $498 \mathrm{Wh}$ in rural Punjab, consisting of one ceiling fan, two mobile charging slots, three LED lights, and one pedestal fan (Table 1).

Table 1. Estimated electricity consumption per rural household.

\begin{tabular}{ccccc}
\hline Appliance & Number in Use & Working Hours & Watts Rating & Total Load (Wh) \\
\hline LED Lights & 3 & 6 & 12 & 216 \\
Charging slots & 2 & 3 & 5 & 30 \\
Ceiling fan & 1 & 14 & 12 & 168 \\
Pedestal fan & 1 & 7 & 12 & 84 \\
\hline \multicolumn{3}{c}{ Total Wh } \\
\hline
\end{tabular}

The total electricity produced at the front end of solar PV and the total electricity demanded is shown by:

$$
\text { Difference of electricity }=\sum_{i=1}^{365}\left(P_{p v_{i}}-P_{d_{i}}\right)
$$

Here, the day of the year is denoted by $i$, total electricity produced, and the total electricity demanded are denoted by $P_{p v_{i}}$ and $P_{d_{i}}$ respectively. Though Equation (9), being parsimonious, apparently does not demonstrate the seasonality considered while estimating the electricity demand, 
however, the seasonal feature has been accounted for while estimating the electricity demand reported in Table 1.

Solar energy cannot be utilized during nighttime. Therefore, energy storage technology is needed to overcome this problem and ensure the non-stop supply of electricity to rural dwellers. Rural Punjab is mostly off-grid. Thus, battery storage is required at an extra cost. The battery storage technique is utilized to store solar energy for later use when there is no sunshine i.e., during the night time or bad weather. If electricity generation is higher than demanded electricity, then there is an electricity excess i.e., $P_{p v_{i}}>P_{d_{i}}$ and this excessive electricity can be saved in the battery. While, if generated electricity is less than demanded electricity, then there is an electricity shortage i.e., $P_{d_{i}}>P_{p v_{i}}$ and the solar PV system is inadequate to fulfill the electricity load. The electricity required to be saved in a battery, annually, $P_{b}$, is therefore given by:

$$
P_{b}=\left(\sum E S-\sum E D\right) \cdot e_{b}
$$

Here, excessive electricity is demoted by $E S$, the electricity deficit by $E D$, while the efficiency of the battery by $e_{b}$. Meanwhile, the daily storage capacity of the battery, $D_{b}$ is computed as:

$$
D_{b}=\frac{P_{b}}{365}
$$

In fact, the calculations only involve the net values of the energy surplus and energy deficit. Further, the supply and demand on an hourly basis would give rich results. However, the current study has used the data on the supply and demand for electricity on an average basis. Therefore, the results obtained based on averages are reasonably explanatory.

\subsubsection{Levelized Cost of Electricity}

The levelized cost of electricity (LCE) is a commonly used metric to compare the electricity cost of different sources. This paper compared the cost of electricity produced by the conventional grid and solar PV to analyze the cost-effectiveness of both technologies. To compare alternative technologies, the estimated levelized cost of electricity/kWh is computed by the following formula [49]:

$$
L C E=\frac{\sum_{k=1}^{n} \frac{I_{c}+M_{c}+F_{c}}{(1+d)^{c}}}{\sum_{k=1}^{n} \frac{E_{a}}{(1+d)^{c}}}
$$

Here, $c$ stands for cost, the investment cost is denoted by $I_{c}$, the maintenance cost by $M_{c}$, the fuel cost by $F_{c}$, the year by $k$, the amount of electricity produced in kWh by $E_{a}$, the discounted rate by $d$ and the operational lifespan of technology by $n$.

\subsection{Emission Mitigation of Solar PV System}

A solar PV system produces clean energy from sunlight and in turn, helps in minimizing greenhouse gas emissions and reduces the reliance on diesel generators [50]. In off-grid areas, diesel generators are commonly used, which possesses high carbon intensity and severely affects human health. On the contrary, solar PV generates very little or no carbon emissions [51,52]. An elevated level of carbon emissions from unhealthy human activities, such as utilizing thermal energy for energy generation has challenged environmental sustainability $[53,54]$. Therefore, if replaced with diesel generators, solar PV can substantially mitigate carbon emissions. The amount of mitigated carbon emissions $D_{s}$ is computed by the following formula, depending on the amount of diesel fuel saved by utilizing solar PV. Therefore, $D_{s}$ is given by [55]:

$$
D_{s}=P_{p v_{i}} X F_{r}
$$


Here, $F_{r}$ is the fuel needed to generate $1 \mathrm{kWh}$ of electricity using a diesel generator. The decrease in carbon emissions is measured in kilogram, while the carbon emission saved by using solar PV is denoted by $C E M_{S}$ and calculated by the following equation.

$$
C E M_{s}=P_{p v_{i}}\left(C_{d}-C_{p v}\right)
$$

Here, $C_{d}$ is the carbon equivalent in kilogram emitted to produce $1 \mathrm{kWh}$ of electricity by using diesel generator, while $C_{p v}$ is the carbon equivalent in $\mathrm{kg}$ emitted to produce $1 \mathrm{kWh}$ of electricity by using solar PV.

\section{Results and Discussion}

The NASA database was accessed to determine solar irradiance in the remote rural regions of Punjab [56]. The most crucial step before utilizing a solar PV system is the identification of solar energy potential in a particular area [57]. The solar irradiance data of the selected regions have been presented in Table 2. It is evident from Table 2 that there is enough solar irradiance in all these regions to produce solar PV-based electricity throughout the year. The research results reveal that the maximum annual solar irradiation was received by Khanewal region $\left(5.50 \mathrm{kWh} / \mathrm{m}^{2}\right)$. The Bhakkar region received $5.46 \mathrm{kWh} / \mathrm{m}^{2}$ annual solar irradiation, followed by the Multan region $\left(5.43 \mathrm{kWh} / \mathrm{m}^{2}\right)$. Whereas, the Rajanpur and Bahawalnagar regions receive annual solar irradiation of 5.41 and $5.37 \mathrm{kWh} / \mathrm{m}^{2}$, respectively (Table 2). Figure 1 shows the average values of annual solar irradiation in these five regions.

Table 2. Solar data for the selected regions of Punjab province.

\begin{tabular}{|c|c|c|c|c|c|c|c|c|c|c|}
\hline \multirow[b]{2}{*}{ Month } & \multicolumn{2}{|c|}{ Bhakkar Region } & \multicolumn{2}{|c|}{ Khanewal Region } & \multicolumn{2}{|c|}{ Multan Region } & \multicolumn{2}{|c|}{ Bahawalpur Region } & \multicolumn{2}{|c|}{ Rajanpur Region } \\
\hline & $\begin{array}{c}\text { Solar Irradiation } \\
\left(\mathbf{k W h} / \mathrm{m}^{2} / \text { day }\right)\end{array}$ & $\begin{array}{l}\text { Earth Temp } \\
\text { (Celsius) }\end{array}$ & - & - & - & - & - & - & - & - \\
\hline Jan & 3.91 & 14.44 & 4.18 & 16.73 & 4.01 & 14.41 & 4.22 & 15.74 & 4.24 & 14.51 \\
\hline $\mathrm{Feb}$ & 4.78 & 18.17 & 4.74 & 20.84 & 4.91 & 18.11 & 4.69 & 19.84 & 4.68 & 19.07 \\
\hline Mar & 5.55 & 24.08 & 5.78 & 27.66 & 5.67 & 25.98 & 5.37 & 27.36 & 5.46 & 25.85 \\
\hline April & 6.46 & 32.94 & 6.18 & 33.78 & 6.48 & 33.85 & 5.61 & 34.62 & 5.64 & 33.95 \\
\hline May & 6.69 & 38.53 & 6.48 & 35.87 & 6.72 & 37.36 & 6.59 & 37.62 & 6.58 & 39.21 \\
\hline June & 6.79 & 41.74 & 6.59 & 37.12 & 6.56 & 39.27 & 6.36 & 39.07 & 6.58 & 40.93 \\
\hline July & 6.73 & 40.48 & 6.68 & 35.96 & 6.63 & 37.72 & 6.33 & 37.75 & 6.71 & 39.73 \\
\hline Aug & 6.55 & 39.07 & 6.47 & 34.19 & 5.72 & 37.25 & 6.31 & 36.54 & 5.81 & 39.21 \\
\hline Sep & 5.65 & 39.08 & 5.98 & 33.26 & 5.63 & 35.56 & 5.39 & 34.76 & 5.63 & 35.82 \\
\hline Oct & 4.74 & 30.23 & 4.78 & 31.28 & 4.84 & 30.69 & 5.14 & 31.32 & 5.28 & 29.83 \\
\hline Nov & 4.22 & 22.78 & 4.12 & 26.36 & 4.04 & 24.18 & 4.37 & 25.58 & 4.23 & 20.84 \\
\hline Dec & 3.51 & 15.86 & 4.06 & 19.05 & 4.04 & 16.71 & 4.15 & 18.29 & 4.19 & 15.04 \\
\hline Average values & 5.46 & 29.78 & 5.50 & 29.34 & 5.43 & 29.25 & 5.37 & 29.87 & 5.41 & 29.49 \\
\hline
\end{tabular}

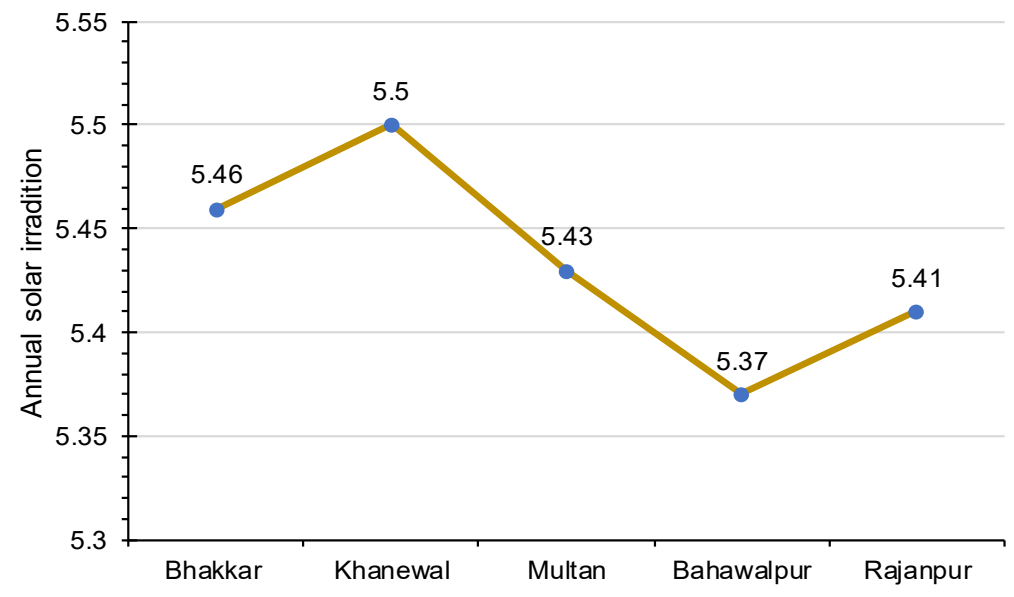

Figure 1. Annual solar irradiation in the rural regions of Punjab. 


\subsection{Analyzing the Potential of Solar Energy}

Besides the average solar irradiation values, the average peak solar hours were also computed for these regions. The total potential of utilizing solar PV in these selected regions has been shown in Table 3. The Khanewal and Bhakkar regions have average solar irradiation of $5.50 \mathrm{kWh} / \mathrm{m}^{2}$ and $5.46 \mathrm{kWh} / \mathrm{m}^{2}$ per day, which can generate annual energy output of $1507 \mathrm{kWh} / \mathrm{kWp}$ and $1496 \mathrm{kWh} / \mathrm{kWp}$ respectively. Meanwhile, each of these regions generates electricity of more than $500 \mathrm{Wh} /$ day from solar PV, which is enough to fulfill the energy requirements of rural households.

Table 3. Electricity generation potential of solar PV in the study regions.

\begin{tabular}{ccccc}
\hline Region & $\begin{array}{c}\text { Daily Solar Irradiation } \\
\left(\mathbf{k W h} / \mathbf{m}^{\mathbf{2}}\right)\end{array}$ & Avg. Peak Solar Hours & $\begin{array}{c}\text { Daily Energy Output } \\
\mathbf{( W h )}\end{array}$ & $\begin{array}{c}\text { Annual Energy Output } \\
\mathbf{( k W h} / \mathbf{k W} \mathbf{p})\end{array}$ \\
\hline Bhakkar & 5.46 & 5.460 & 5460 & 1495 \\
Khanewal & 5.50 & 5.500 & 5500 & 1506 \\
Multan & 5.43 & 5.430 & 5430 & 1486 \\
Bahawalpur & 5.37 & 5.370 & 5240 & 1470 \\
Rajanpur & 5.41 & 5.410 & 5280 & 1481 \\
\hline
\end{tabular}

\subsection{Solar Irradiation Received at the Optimal Tilt Angle}

By using the Equations (2)-(6), the daily solar irradiation's mean values have been calculated and shown in Table 4. It was revealed that by changing the angle of solar PV panels from $0^{\circ}-90^{\circ}$, energy output increased considerably. For instance, at the optimal tilt angle of $28.9^{\circ}$, energy yield increased by $9.86 \%$ in Bhakkar, while $10.28 \%$ in Khanewal at the optimal tilt angle of $28.7^{\circ}$. Similarly, it increased by $10.35 \%$ in Multan at $28.6^{\circ}, 9.74 \%$ at $29.8^{\circ}$ in Bahawalnagar, and $10.9 \%$ at $29.4^{\circ}$ in Rajanpur respectively. A graphical representation of the optimal tilt angles along with the energy yields for the respective regions included in the given sample is reported in Figure 2, based on the solar irradiation data which we have collected every month for one year in all these regions (Table S1).

Table 4. Solar irradiance ( $\mathrm{kWh} / \mathrm{m}^{2} /$ day) received on a tilted angle from 0-90 degrees.

\begin{tabular}{ccccc}
\hline Region & $\mathbf{0}^{\circ}$ Tilt Angle & $\mathbf{3 0}^{\circ}$ Tilt Angle & $\mathbf{6 0}^{\circ}$ Tilt Angle & $\mathbf{9 0}^{\circ}$ Tilt Angle \\
\hline Bhakkar & 5.6 & 6.1 & 5.4 & 3.7 \\
Khanewal & 5.3 & 5.8 & 5.2 & 3.5 \\
Multan & 5.5 & 6.1 & 5.5 & 3.8 \\
Bahawalpur & 5.7 & 6.2 & 5.5 & 3.8 \\
Rajanpur & 5.5 & 6.3 & 5.6 & 3.6 \\
\hline
\end{tabular}

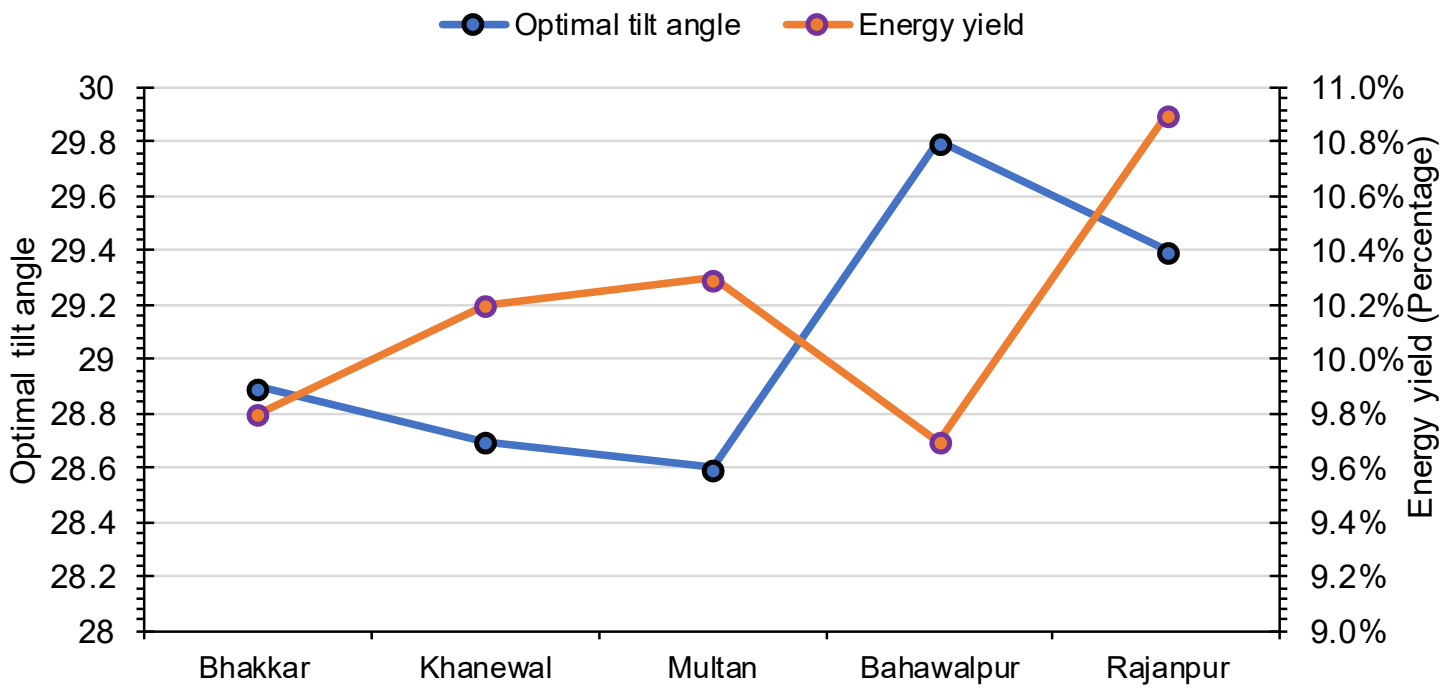

Figure 2. Optimal tilt angles along with the energy yields for the respective regions. 


\subsection{Economic Viability of Solar PV System}

This study proposed an off-grid solar PV system for rural electrification in Punjab province. The simulation of the parameters has been presented in Table 5 [58]. By using Equations (7)-(11), it was found that the PV module area was $1.2 \mathrm{~m}^{2}$, whereas the maximum current and voltage were $7.70 \mathrm{~A}$ and $28.5 \mathrm{~V}$, respectively. Abdullah et al. [59] identified that a solar PV system with a generation capacity of $200 \mathrm{~W}$ is suitable to electrify one home. Thus, a $200 \mathrm{~W}$ solar panel having a $140 \mathrm{Ah} / 12 \mathrm{~V}$ battery and conversion efficiency of $16 \%$ is appropriate for the electricity needs of one household. All these five regions generate maximum electricity from April to July. However, electricity generation slightly reduced during monsoon season i.e., from August to October. Electricity generation continues to decline through January and then starts to increase in February.

Table 5. Parameters used in the research.

\begin{tabular}{ccc}
\hline Parameters & Unit & Value \\
\hline Area of panel & $\mathrm{m}^{2}$ & 1.2 \\
Power current (Max) & $\mathrm{A}$ & 7.70 \\
Power voltage (Max) & $\mathrm{V}$ & 28.5 \\
Power rating of solar PV & $\mathrm{WP}$ & 200 \\
Average Life of solar PV & Year & 25 \\
Capital cost of solar PV & PKR/WP & 110 \\
Efficiency of solar PV & $\%$ & 16 \\
Efficiency of battery & $\%$ & 85 \\
Cost of battery & PKR/Ah & 120 \\
Life of battery & Year & 5 \\
\hline
\end{tabular}

The cost of solar PV module accounts for $5.72 \%$ of the total installation cost, whereas, the battery cost is approximately $18.3 \%$. The system's life cycle is 25 years. However, the batteries need to be replaced four times, as they have a life cycle time of approximately 5 years. This means that the total cost of the batteries is approximately $91.5 \%$ of the total installation cost. The charge regulator, inverter, circuit breaker, civil work, and system controller are the other components of the solar PV system which account for the extra costs [60]. The cost of all these components has been shown in Table 6. Using Equation (12), the LCE of the proposed system was calculated and it was PKR 7.15/kWh, whereas the cost of electricity from the traditional grid was PKR 20.7/kWh [58]. Therefore, the solar PV system saves PKR 13.5/kWh for each household.

Table 6. Installation cost of the components used in off-grid solar photovoltaic (PV) system.

\begin{tabular}{cccccc}
\hline No. & Components & Quantity & Life Time (Years) & Price (PKR) & Percentage Share of Price \\
\hline 1 & Solar PV panel & 1 & 20 & 5000 & 5.72 \\
2 & Battery & 1 & 5 & 16,000 & 18.3 \\
3 & Inverter & 1 & 20 & 250 & 0.28 \\
4 & Civil work & - & 20 & 1000 & 1.14 \\
5 & Charge regulator & 1 & 20 & 275 & 0.31 \\
6 & Circuit breaker & 1 & 20 & 300 & 0.34 \\
7 & Battery replacement & 4 & 20 & 64,000 & 73.2 \\
8 & System controller & 1 & 20 & 500 & 0.57 \\
\hline
\end{tabular}

\subsection{Emissions Mitigation from the Solar PV Power Generation System}

A typical $20 \mathrm{~kW}$ diesel generator produces $4 \mathrm{kWh}$ of electricity by using 1 liter (L) of diesel [61]. To fulfill the annual electricity demand of $181.8 \mathrm{kWh}$ for the above household example, a diesel generator needs to consume 45.4 L diesel annually. Thus, according to Equation (14), the proposed solar PV system can mitigate $97.50 \mathrm{~kg} \mathrm{CO}_{2}$ per household annually. There are 6,328,418 households in 
rural Punjab, according to seventh senses of Pakistan [62]. If solar PV system provides $100 \%$ electricity to these households, then approximately 617,020 metric tons of $\mathrm{CO}_{2}$ would be mitigated annually.

\section{Conclusions and Policy Recommendations}

\subsection{Conclusions}

The off-grid solar PV system has been identified as the best energy option to electrify rural regions of Punjab province due to its easy installation, transportation, and maintenance. However, before installing the off-grid solar PV power generation system, it is essential to assess and analyze the techno-economic feasibility of these regions. Therefore, five rural regions, namely Bhakkar, Khanewal, Multan, Bahawalnagar, and Rajanpur were selected, and their techno-economic feasibility was evaluated in this study. A systematic method was developed to assess the solar PV potential of these regions. Solar radiation received on a horizontal surface was assessed firstly. Secondly, the optimal tilt angles were calculated to maximize solar energy output in the respective regions. As rural regions lack the technology required for tracking the sun to increase energy yield. Therefore, the optimal tilt angle is very useful for rural regions. Although solar trackers are available in the market, they are very costly, making them unsuitable for rural regions. The research results show that all these regions have enormous solar energy potential and are suitable for electricity generation. Meanwhile, by varying the angle of solar PV on the optimal tilt angle, the energy output could be increased significantly. It was also found that conventional energy sources are more expensive than the off-grid solar PV system as electricity generation from conventional sources is PKR $20.7 / \mathrm{kWh}$, while it is only PKR $7.15 / \mathrm{kWh}$ for the off-grid solar PV system. The study reveals that 617,020 metric tons of $\mathrm{CO}_{2}$ could be mitigated annually by electrifying 100\% rural households with the off-grid solar PV system in Punjab province. The role of the Pakistani government is very crucial in this respect. The government should formulate a strong policy framework to reduce the dependence on conventional energy sources and electrify rural regions with off-grid solar PV system because the fragile economy of Pakistan is unable to afford the import of costly thermal sources, especially oil. Moreover, the government should learn from neighboring countries i.e., Bangladesh and India, as they have successfully implemented rural electrification programs $[63,64]$, and share key geographic, social and economic similarities with Pakistan. Finally, essential policy recommendations have been provided for all stakeholders. Government and stakeholders can take benefit from this study, use it as a guide and make procurement strategies accordingly.

\subsection{Policy Recommendations}

The following policy recommendations are suggested for the quick deployment of off-grid solar PV rural electrification programs in Punjab province.

- The research results reveal that all these five rural regions have vast solar energy potential for electricity generation. Therefore, the related authorities should take the initiative and make effective strategies to initiate the off-grid solar PV rural programs.

- Though all the regions have a good potential for solar energy, yet Khanewal is most appropriate as it has the highest solar energy potential among all these regions. Moreover, the geographical location of this region is technically and economically best for solar energy generation. Therefore, the government should focus on this region on a priority basis.

- Besides opportunities, there exist barriers as well. Previous studies indicate that the major barriers in the deployment of solar electricity generation are lack of political will and weak government policies $[65,66]$. Thus, it is advised that the government should announce supportive policies for the maximum utilization of solar energy.

- Some rural solar energy projects did not produce the desired results in the past and failed. Investors are reluctant to invest in new projects. Therefore, a robust policy framework is needed, which allows investors to believe in the investment environment. 
- Monetary benefits and tax concessions should be provided to local developers so that they invest more willingly in new solar PV projects.

- Other key barriers are the unavailability of government subsidies and bank loans to buy solar PV systems. Thus, the government should establish micro-financing projects and provide subsidies which encourages rural dwellers to buy off-grid solar PV solutions.

- The existing policy structure gives priority to conventional energy sources instead of renewable energy. Therefore, this policy structure needs reformations by giving high preference to renewable sources.

- There is a need to reduce the upfront capital cost of the solar PV system so that rural residents can easily buy and install solar PV systems.

- The masses should be educated about the benefits associated with solar energy utilization and make them aware of the harms related to conventional energy. This can be done by organizing seminars and awareness campaigns at the local level.

- The government should launch training programs and cultivate local professionals to manage, install and operate solar PV system.

\subsection{Limitations and Future Research Directions}

The research also has some limitations. Only considered five rural regions of Punjab province were considered. Therefore, the research findings are unsuitable for other regions and provinces of Pakistan. Future researchers can take a techno-economic feasibility analysis of off-grid solar PV power generation to other regions of the country. Moreover, researchers can consider developing a hybrid renewable energy system, like wind and solar, in rural areas to make them independent of the national grid. Above all, the government's role is very crucial to assist rural regions with such hybrid systems and overcome the energy crises of Pakistan.

In current study, the calculations only involved the net values of energy surplus and energy deficit, and this is considered as the limitation of current research. Furthermore, supply and demand on hourly basis would give rich results. However, the current study has used the data on supply and demand of electricity on an average basis. Thus, it may be taken as a vital future research direction.

Supplementary Materials: The following are available online at http://www.mdpi.com/2227-9717/7/10/708/s1, Table S1: Solar irradiance $\left(\mathrm{kWh} / \mathrm{m}^{2} /\right.$ day) received on a tilted angle from 0-90 degrees in different regions.

Author Contributions: Conceptualization, M.I.; data curation, M.I. and M.A.; formal analysis, M.I. and Z.-y.Z.; funding acquisition, Z.-y.Z.; writing-original draft, M.I.; writing—review \& editing, M.A., M.K.P., F.H.M. and A.R.

Funding: This work is supported by Beijing Natural Science Foundation (8192043).

Conflicts of Interest: The authors declare no potential conflict of interest.

\section{References}

1. Warner, K.J.; Jones, G.A. A Population-Induced Renewable Energy Timeline in Nine World Regions. Energy Policy 2017, 101, 65-76. [CrossRef]

2. International Energy Agency (IEA). World Energy Outlook 2017; International Energy Agency: Paris, France, 2017; pp. 1-15.

3. Das, H.S.; Dey, A.; Tan, C.W.; Yatim, A.H.M. Feasibility analysis of standalone PV/wind/battery hybrid energy system for rural Bangladesh. Int. J. Renew. Energy Res. 2016, 6, 402-412.

4. Raheem, A.; Abbasi, S.A.; Memon, A.; Samo, S.R.; Taufiq-Yap, Y.H.; Danquah, M.K.; Harun, R. Renewable Energy Deployment to Combat Energy Crisis in Pakistan. Energy Sustain. Soc. 2016, 6, 16. [CrossRef]

5. Mirjat, N.H.; Uqaili, M.A.; Harijan, K.; Das Valasai, G.; Shaikh, F.; Waris, M. A Review of Energy and Power Planning and Policies of Pakistan. Renew. Sustain. Energy Rev. 2017, 79, 110-127. [CrossRef]

6. Rehman, S.A.U.; Cai, Y.; Fazal, R.; Das Walasai, G.; Mirjat, N.H. An Integrated Modeling Approach for Forecasting Long-Term Energy Demand in Pakistan. Energies 2017, 10, 1868. [CrossRef] 
7. Irfan, M.; Zhao, Z.Y.; Ahmad, M.; Mukeshimana, M.C. Solar Energy Development in Pakistan: Barriers and Policy Recommendations. Sustainability 2019, 11, 1206. [CrossRef]

8. Sharma, A.; Srivastava, J.; Kar, S.K.; Kumar, A. Wind energy status in India: A short review. Renew. Sustain. Energy Rev. 2012, 16, 1157-1164. [CrossRef]

9. Solangi, Y.A.; Tan, Q.; Mirjat, N.H.; Das Valasai, G.; Khan, M.W.A.; Ikram, M. An Integrated Delphi AHP and Fuzzy TOPSIS Approach toward Ranking and Selection of Renewable Energy Resources in Pakistan. Processes 2019, 7, 118. [CrossRef]

10. Qayyum, S. Pakistan: A Renewable Energy State? Available online: http://www.technologyreview.pk/ pakistan-a-renewable-energy-state/ (accessed on 22 March 2019).

11. Bhutto, A.W.; Bazmi, A.A.; Zahedi, G. Greener Energy: Issues and Challenges for Pakistan-Solar Energy Prospective. Renew. Sustain. Energy Rev. 2012, 16, 2762-2780. [CrossRef]

12. Arefin, M.A.; Mallik, A.; Asfaquzzaman, M. Renewable energy-assisted hybrid three-wheeler: A numerical investigation. Adv. Mech. Eng. 2018, 10, 1687814018814372. [CrossRef]

13. Mirza, U.K.; Ahmad, N.; Harijan, K.; Majeed, T. Identifying and Addressing Barriers to Renewable Energy Development in Pakistan. Renew. Sustain. Energy Rev. 2009, 13, 927-931. [CrossRef]

14. Irfan, M.; Zhao, Z.Y.; Mukeshimana, M.C.; Ahmad, M. Wind Energy Development in South Asia: Status, Potential and Policies. In Proceedings of the 2019 2nd International Conference on Computing, Mathematics and Engineering Technologies (iCoMET) 2019, Karachi, Pakistan, 30-31 January 2019; pp. 1-6.

15. Bataineh, A.; Alqudah, A.; Athamneh, A. Optimal design of hybrid power generation system to ensure reliable power supply to the health center at Umm Jamal, Mafraq, Jordan. Energy Environ. Res 2014, 4, 9. [CrossRef]

16. Wakeel, M.; Chen, B.; Jahangir, S. Overview of Energy Portfolio in Pakistan. Energy Procedia 2016, 88, 71-75. [CrossRef]

17. Hasnie, S. How the un-Electrified Poor Can Leapfrog to Off-Grid Solar. Available online: https://blogs.adb. org/blog/how-unelectrified-poor-can-leapfrog-grid-solar (accessed on 17 April 2019).

18. Mamaghani, A.H.; Escandon, S.A.A.; Najafi, B.; Shirazi, A.; Rinaldi, F. Techno-Economic Feasibility of Photovoltaic, Wind, Diesel and Hybrid Electrification Systems for off-Grid Rural Electrification in Colombia. Renew. Energy 2016, 97, 293-305.

19. Ghafoor, A.; Munir, A. Design and Economics Analysis of an Off-Grid PV System for Household Electrification. Renew. Sustain. Energy Rev. 2015, 42, 496-502. [CrossRef]

20. Sandwell, P.; Chan, N.L.A.; Foster, S.; Nagpal, D.; Emmott, C.J.M.; Candelise, C.; Buckle, S.J.; Ekins-Daukes, N.; Gambhir, A.; Nelson, J. Off-Grid Solar Photovoltaic Systems for Rural Electrification and Emissions Mitigation in India. Sol. Energy Mater. Sol. Cells 2016, 156, 147-156. [CrossRef]

21. Mishra, P.; Behera, B. Socio-Economic and Environmental Implications of Solar Electrification: Experience of Rural Odisha. Renew. Sustain. Energy Rev. 2016, 56, 953-964. [CrossRef]

22. Hosenuzzaman, M.; Rahim, N.A.; Selvaraj, J.; Hasanuzzaman, M.; Malek, A.B.M.A.; Nahar, A. Global Prospects, Progress, Policies, and Environmental Impact of Solar Photovoltaic Power Generation. Renew. Sustain. Energy Rev. 2015, 41, 284-297. [CrossRef]

23. Kerekes, T.; Koutroulis, E.; Séra, D.; Teodorescu, R.; Katsanevakis, M. An Optimization Method for Designing Large PV Plants. IEEE J. Photovolt. 2013, 3, 814-822. [CrossRef]

24. Islam, M.R.; Guo, Y.; Zhu, J. A Multilevel Medium-Voltage Inverter for Step-up-Transformer-Less Grid Connection of Photovoltaic Power Plants. IEEE J. Photovolt. 2014, 4, 881-889. [CrossRef]

25. Nasir, M.; Khan, H.A.; Hussain, A.; Mateen, L.; Zaffar, N.A. Solar PV Based Scalable DC Microgrid for Rural Electrification in Developing Regions. IEEE Trans. Sustain. Energy 2018, 9, 390-399. [CrossRef]

26. Shaikh, P.H.; Shaikh, F.; Mirani, M. Solar Energy: Topographical Asset for Pakistan. Appl. Sol. Energy 2013, 49, 49-53. [CrossRef]

27. Solangi, Y.A.; Tan, Q.; Khan, M.W.A.; Mirjat, N.H.; Ahmed, I. The Selection of Wind Power Project Location in the Southeastern Corridor of Pakistan: A Factor Analysis, AHP, and Fuzzy-TOPSIS Application. Energies 2018, 11, 1940. [CrossRef]

28. AEDB. Progress so Far Made in Solar Power Sector in Pakistan. Available online: https://www.aedb.org/ aetechnologies/solar-power/solar-current-status (accessed on 18 May 2019).

29. NEPRA. State of Industry Report 2016. Available online: http://www.nepra.org.pk/ (accessed on 12 March 2019). 
30. Urmee, T.; Harries, D.; Schlapfer, A. Issues Related to Rural Electrification Using Renewable Energy in Developing Countries of Asia and Pacific. Renew. Energy 2009, 34, 354-357. [CrossRef]

31. Dawn. Solar Energy Production Fails to Take off Despite Electricity Crisis. Available online: https://www.dawn.com/news/1194261 (accessed on 23 May 2019).

32. Harijan, K.; Uqaili, M.; Mirza, U. Assessment of Solar PV Power Generation Potential in Pakistan. J. Clean Energy Technol. 2015, 3, 54-56. [CrossRef]

33. Bhutta, F.M. Solar PV Opportunities and Challenges in Pakistan. April 2015. Available online: http://engghorizons.com/solar-pv-opportunities-and-challenges-in-pakistan/ (accessed on 13 May 2019).

34. Benghanem, M. Optimization of Tilt Angle for Solar Panel: Case Study for Madinah, Saudi Arabia. Appl. Energy 2011, 88, 1427-1433. [CrossRef]

35. Chrobak, P.; Skovajsa, J.; Zalesak, M. Effect of cloudiness on the production of electricity by photovoltaic panels. In MATEC Web of Conferences; EDP Sciences: Les Ulis, France, 2016; Volume 76, p. 02010.

36. Nasir, M.; Zia, M.F. Global maximum power point tracking algorithm for photovoltaic systems under partial shading conditions. In Proceedings of the 2014 16th International Power Electronics and Motion Control Conference and Exposition, Antalya, Turkey, 21-24 September 2014; pp. 667-672.

37. Bonkaney, A.; Madougou, S.; Adamou, R. Impacts of cloud cover and dust on the performance of photovoltaic module in Niamey. J. Renew. Energy 2017. [CrossRef]

38. Kelly, N.A.; Gibson, T.L. Improved photovoltaic energy output for cloudy conditions with a solar tracking system. Sol. Energy 2009, 83, 2092-2102. [CrossRef]

39. Barker, L.; Neber, M.; Lee, H. Design of a Low-Profile Two-Axis Solar Tracker. Sol. Energy 2013, 97, 569-576. [CrossRef]

40. Shah, S.A.A.; Das Valasai, G.; Memon, A.A.; Laghari, A.N.; Jalbani, N.B.; Strait, J.L. Techno-Economic Analysis of Solar PV Electricity Supply to Rural Areas of Balochistan, Pakistan. Energies 2018, 11, 1777. [CrossRef]

41. Skeiker, K. Optimum Tilt Angle and Orientation for Solar Collectors in Syria. Energy Convers. Manag. 2009, 50, 2439-2448. [CrossRef]

42. Hartner, M.; Ortner, A.; Hiesl, A.; Haas, R. East to West-The Optimal Tilt Angle and Orientation of Photovoltaic Panels from an Electricity System Perspective. Appl. Energy 2015, 160, 94-107. [CrossRef]

43. Rowlands, I.H.; Kemery, B.P.; Beausoleil-Morrison, I. Optimal Solar-PV Tilt Angle and Azimuth: An Ontario (Canada) Case-Study. Energy Policy 2011, 39, 1397-1409. [CrossRef]

44. Liu, B.; Jordan, R. Daily Insolation on Surfaces Tilted towards Equator. ASHRAE Trans. 1962, 67, 526-541.

45. Kotak, Y.; Gul, M.S.; Muneer, T. Investigating the Impact of Ground Albedo on the Performance of PV Systems. In Proceedings of the CIBSE Technical Symposium, London, UK, 16-17 April 2015.

46. Stojanovski, O.; Thurber, M.; Wolak, F. Rural Energy Access through Solar Home Systems: Use Patterns and Opportunities for Improvement. Energy Sustain. Dev. 2017, 37, 33-50. [CrossRef]

47. Okoye, C.O.; Oranekwu-Okoye, B.C. Economic Feasibility of Solar PV System for Rural Electrification in Sub-Sahara Africa. Renew. Sustain. Energy Rev. 2018, 82, 2537-2547. [CrossRef]

48. Okoye, C.O.; Taylan, O.; Baker, D.K. Solar Energy Potentials in Strategically Located Cities in Nigeria: Review, Resource Assessment and PV System Design. Renew. Sustain. Energy Rev. 2016, 55, 550-566. [CrossRef]

49. Baurzhan, S.; Jenkins, G.P. Off-Grid Solar PV: Is It an Affordable or Appropriate Solution for Rural Electrification in Sub-Saharan African Countries? Renew. Sustain. Energy Rev. 2016, 60, 1405-1418. [CrossRef]

50. Isa, N.M.; Das, H.S.; Tan, C.W.; Yatim, A.H.M.; Lau, K.Y. A techno-economic assessment of a combined heat and power photovoltaic/fuel cell/battery energy system in Malaysia hospital. Energy 2016, 112, 75-90. [CrossRef]

51. Jabeen, M.; Umar, M.; Zahid, M.; Rehaman, M.U.; Batool, R.; Zaman, K. Socio-Economic Prospects of Solar Technology Utilization in Abbottabad, Pakistan. Renew. Sustain. Energy Rev. 2014, 39, 1164-1172. [CrossRef]

52. Nandi, S.K.; Ghosh, H.R. A wind-PV-battery hybrid power system at Sitakunda in Bangladesh. Energy Policy 2009, 37, 3659-3664. [CrossRef]

53. Ikram, M.; Mahmoudi, A.; Shah, S.Z.A.; Mohsin, M. Forecasting Number of ISO 14001 Certifications of Selected Countries: Application of Even GM (1,1), DGM, and NDGM Models. Environ. Sci. Pollut. Res. 2019, 26, 12505-12521. [CrossRef] 
54. Ali, S.; Xu, H.; Ahmed, W.; Ahmad, N.; Solangi, Y.A. Metro Design and Heritage Sustainability: Conflict Analysis Using Attitude Based on Options in the Graph Model. Environ. Dev. Sustain. 2019, 1-22. [CrossRef]

55. Baurzhan, S.; Jenkins, G.P. On-Grid Solar PV versus Diesel Electricity Generation in Sub-Saharan Africa: Economics and GHG Emissions. Sustainability 2017, 9, 372. [CrossRef]

56. NASA-POWER Project Data Sets. Available online: https://power.larc.nasa.gov/ (accessed on 16 February 2019).

57. Kharseh, M.; Wallbaum, H. How Adding a Battery to a Grid-Connected Photovoltaic System Can Increase Its Economic Performance: A Comparison of Different Scenarios. Energies 2019, 12, 30. [CrossRef]

58. Ullah, H.; Kamal, I.; Ali, A.; Arshad, N. Investor Focused Placement and Sizing of Photovoltaic Grid-Connected Systems in Pakistan. Renew. Energy 2018, 121, 460-473. [CrossRef]

59. Abdullah; Zhou, D.; Shah, T.; Jebran, K.; Ali, S.; Ali, A.; Ali, A. Acceptance and Willingness to Pay for Solar Home System: Survey Evidence from Northern Area of Pakistan. Energy Rep. 2017, 3, 54-60. [CrossRef]

60. Pakistan Economic Survey. Pakistan Economic Survey Report 2018-2019. Available online: http://finance. gov.pk/survey/chapters_19/Economic_Survey_2018_19.pdf (accessed on 14 August 2019).

61. Xu, L.; Wang, Y.; Solangi, Y.A.; Zameer, H.; Shah, S.A.A. Off-Grid Solar PV Power Generation System in Sindh, Pakistan: A Techno-Economic Feasibility Analysis. Processes 2019, 7, 308. [CrossRef]

62. Pakistan Bureau of Statistics. 7th Population and Housing Census. Available online: http://www.pbs.gov.pk/ (accessed on 13 April 2019).

63. Malakar, Y. Evaluating the Role of Rural Electrification in Expanding People's Capabilities in India. Energy Policy 2018, 114, 492-498. [CrossRef]

64. Rahman, M.M.; Paatero, J.V.; Poudyal, A.; Lahdelma, R. Driving and Hindering Factors for Rural Electrification in Developing Countries: Lessons from Bangladesh. Energy Policy 2013, 61, 840-851. [CrossRef]

65. Zafar, U.; Ur Rashid, T.; Khosa, A.A.; Khalil, M.S.; Rahid, M. An Overview of Implemented Renewable Energy Policy of Pakistan. Renew. Sustain. Energy Rev. 2018, 82, 654-665. [CrossRef]

66. Zameer, H.; Wang, Y. Energy Production System Optimization: Evidence from Pakistan. Renew. Sustain. Energy Rev. 2018, 82, 886-893. [CrossRef]

(C) 2019 by the authors. Licensee MDPI, Basel, Switzerland. This article is an open access article distributed under the terms and conditions of the Creative Commons Attribution (CC BY) license (http://creativecommons.org/licenses/by/4.0/). 